\title{
PENGARUH KOMUNIKASI ORGANISASI DAN KOMPENSASI TERHADAP SEMANGAT KERJA KARYAWAN
}

\author{
Dwi Agung Nugroho Arianto \\ Universitas Islam Nahdhatul Ulama Jepara, Indonesia \\ Email:goeng_nugroho@yahoo.co.id
}

\begin{abstract}
Abstrak: Pengaruh Komunikasi Organisasi dan Kompensasi Terhadap Semangat Kerja Karyawan. Penelitian ini bertujuan untuk menganalisis pengaruh dan dampak komunikasi organisasi dan kompensasi terhadap semangat kerja karyawan. Penelitian ini menggunakan pendekatan kuantitatif dengan analisis data menggunakan regresi linier berganda. Pengumpulan data menggunakan metode angket (kuesioner). Populasi penelitian adalah seluruh karyawan PT. Vermindo Utama Semarang. Hasil penelitian menunjukkan komunikasi organisasi berpengaruh positif terhadap semangat kerja karyawan. Hal ini berarti dengan komunikasi yang intens permasalahan dalam perusahaan akan mudah terselesaikan. Kompensasi berpengaruh positif terhadap semangat kerja karyawan. Hal ini menunjukkan bahwa kompensasi baik berupa finansial maupun fasilitas akan meningkatkan semangat kerja karyawan.
\end{abstract}

Kata kunci: komunikasi organisasi, kompensasi, semangat kerja.

Abstract: The influence of Organization Communication and Compensation on Employee Morale. This study aims to analyze the influence and impact of organizational communication and compensation on employee morale. This study uses a quantitative approach and employ a multiple linear regression approach to analyze the data. The data is taken from employees of PT. Vermindo Utama Semarang. The results show that organization communication has a positive effect on the employee morale. Another finding is the compensation has a positive effect on employee morale.

Keywords: organizational communication, compensation, employee morale

\section{PENDAHULUAN}

Suatu perusahaan memerlukan sebuah sistem yang dapat menunjang kinerja perusahaan tersebut. Salah satunya adalah semangat kerja yang tinggi. Semangat kerja merupakan keadaan yang harus ada bila aktivitas atau proses kerja ingin berjalan lancar. Tujuan organisasi dapat tercapai sesuai rencana apabila ada semangat kerja yang tinggi.

Semangat kerja adalah melakukan pekerjaan secara lebih giat, sehingga dengan demikian pekerjaan akan dapat diharapkan lebih cepat dan lebih baik. (Nitisemito, 2002: 160). Menurut Nitisemito (2002: 83) hal-hal yang mempengaruhi semangat kerja karyawan adalah jumlah dan komposisi dari kompensasi yang diberikan, penempatan yang tepat, latihan rasa aman dimasa depan, mutasi, promosi dan lingkungan kerja. Sedangkan Zainun (2000: 67) mengatakan bahwa komunikasi juga mempengaruhi semangat kerja karyawan. Jadi dapat disimpulkan bahwa semangat kerja 
karyawan dipengaruhi oleh komunikasi, kompensasi, lingkungan kerja, dan pengembangan karyawan.

Untuk mencapai tujuan perusahaan yang diharapkan sangat membutuhkan proses yang lama, salah satunya proses komunikasi harus berjalan efektif karena komunikasi merupakan bagian integral dari suatu proses manajemen. Melalui komunikasi yang efektif, kerja sama yang harmonis dapat dikembangkan untuk mencapai tujuan (Nitisemito, 2002: 22). Seperti yang dikatakan pula oleh Terry (2006: 207) bahwa komunikasi menempati urutan teratas dan berpengaruh terhadap antusiasme kerja. Kerjasama dapat dibentuk melalui komunikasi antara pimpinan maupun karyawan dalam memberikan keterangan tentang pekerjaan kepada karyawan lain. Kerja sama yang harmonis ini diharapkan dapat meningkatkan kerja para karyawan, karena komunikasi berhubungan secara langsung terhadap proses pembinaan perilaku manusia dalam organisasi.

Hal ini diperkuat dari hasil penelitian Rochim dalam Jurnal Dinamika Manajemen Vol. 1 No. 2 halaman 103-113 tahun 2012 yang menunjukkan bahwa komunikasi berpengaruh signifikan terhadap semangat kerja, artinya bahwa semakin inten komunikasi yang dilakukan maka akan semakin meningkatkan semangat kerja.

Salah satu tantangan besar di dalam komunikasi organisasi adalah bagaimana menyampaikan informasi keseluruh bagian organisasi dan bagaimana menerima informasi dari seluruh bagian organisasi. Proses ini berhubungan dengan aliran informasi. Aliran informasi itu sendiri ada tiga cara yaitu serentak, berurutan dan kombinasi keduanya. Maka dalam komunikasi organisasi dibutuhkan kerja sama yang baik dengan pimpinan, bawahan, maupun sesama karyawan dalam pemberian perintah, laporan atau musyawarah.

Hubungan yang tercipta dalam perusahaan baik antara pimpinan dengan karyawan atau dengan sesama karyawan sangat mempengaruhi semangat kerja karyawan. Komunikasi sebagai proses pemberitahuan dari satu pihak ke pihak lain yang dapat berupa rencana-rencana, instruksi-instruksi, petunjuk-petunjuk, dan saran-saran. Dari pengertian tersebut pelaksanaan komunikasi dapat dibedakan dalam tiga macam, yaitu: keterangan dan ide-ide yang disampaikan oleh pimpinan, bawahan dan sejawat (Nitisemito, 2002: 239).

Dengan demikian pelaksanaan komunikasi organisasi sangat diperlukan untuk melancarkan tugas-tugas karyawan. Sering terlihat dalam perusahaan atau instansi, jika hubungan antara pimpinan dan bawahan kurang baik maka para karyawan dalam melaksanakan tugasnya akan semakin malas. Tetapi sebaliknya jika hubungan atasan dengan bawahan baik maka karyawan juga lebih semangat dalam melaksanakan pekerjaannya.

Penelitian ini mengambil objek penelitian di PT. Vermindo Utama Semarang. Berdasarkan teori di atas, maka peneliti berusaha mencari informasi dan data tentang komunikasi organisasi dan kompensasi yang terdapat pada PT. Vermindo Utama Semarang. Hal ini peneliti lakukan dengan cara observasi awal yaitu dengan pengamatan langsung dan wawancara kepada beberapa karyawan. 
Peneliti melakukan observasi awal dalam waktu kurang lebih satu minggu. Berdasarkan hasil observasi awal peneliti di PT. Vermindo Utama Semarang, ditemukan data bahwa ada jarak dalam komunikasi antara pimpinan dengan karyawan dan karyawan dengan teman sejawat. Hal ini terlihat ketika pimpinan memberikan perintah kepada karyawan. Karyawan hanya menunduk dan pimpinan tidak menjelaskan perintah secara detail. Sehingga karyawan nampak ketakutan, bukan karena menjalankan perintah atas dasar tanggungjawab. Selain itu komunikasi secara langsung juga jarang terjadi dalam perusahaan.

Selain faktor komunikasi, ada juga faktor yang mempengaruhi semangat kerja karyawan yaitu kompensasi. Hal ini sesuai dengan pendapat Nitisemito (2002: 83) bahwa hal-hal yang mempengaruhi semangat kerja karyawan adalah salah satunya jumlah dan komposisi dari kompensasi yang diberikan.

Kompensasi sangat penting bagi karyawan, karena besarnya kompensasi merupakan pencerminan atau ukuran nilai pekerjaan karyawan itu sendiri. Sebaliknya besar kecilnya kompensasi dapat mempengaruhi semangat kerja. Apabila kompensasi diberikan secara tepat dan benar para karyawan akan lebih berprestasi untuk mencapai tujuan-tujuan organisasi.

Pernyataan di atas telah dibuktikan oleh penelitian Danti (2014) yang menunjukkan bahwa secara bersama-sama kompensasi langsung dan tidak langsung berpengaruh terhadap semangat kerja karyawan CV. Sejahtera Pakisaji Malang. Dari kedua variabel tersebut, variabel kompensasi tidak langsung mempunyai pengaruh yang dominan terhadap semangat kerja karyawan.

Berdasarkan studi lapangan dan wawancara awal dengan pemilik PT. Vermindo Utama bahwa program kompensasi yang diberikan oleh PT. Vermindo Utama Semarang antara lain: 1) gaji terbagi menjadi dua yaitu gaji bulanan dan gaji lembur, 2) insentif berupa bonus dan penghargaan, biasanya diberikan kepada karyawan teladan, 3) tunjangan, berupa tunjangan hari raya, tunjangan kesehatan, kecelakaan kerja, tunjangan perkawinan, tunjangan kematian, 4) fasilitas berupa tempat kerja, pakaian kerja, cuti kerja dan transportasi.

Berdasarkan penjelasan tersebut, terlihat bahwa PT. Vermindo Utama berusaha memberikan kompensasi yang baik untuk meningkatkan semangat kerja karyawannya. Bagi PT. Vermindo Utama semangat kerja karyawan sangat diperlukan untuk meningkatkan tujuan perusahaan. Hal inilah yang akhirnya membuat peneliti tertarik untuk mengadakan penelitian tentang pengaruh komunikasi organisasi dan kompensasi terhadap semangat kerja karyawan di PT. Vermindo Utama Semarang. Hasil penelitian ini diharapkan dapat bermanfaat bagi perusahaan-perusahaan besar maupun kecil dan home industri yang memperkerjakan karyawan, dimana berhasil tidaknya perusahaan bergantung pada unsur manusia yang melakukan pekerjaan oleh sebab itu perlu adanya balas jasa. Seorang karyawan harus diperlakukan dengan baik selayaknya manusia dan pemberian kompensasi adalah sebagai salah satu wujud tanggung jawab perusahaan. 
Sesuai dengan permasalahan penelitian yang ada, maka penelitian ini bertujuan: (1) Untuk menganalisis pengaruh komunikasi organisasi terhadap semangat kerja karyawan PT. Vermindo Utama semarang. (2) Menganalisis pengaruh kompensasi terhadap semangat kerja karyawan PT. Vermindo Utama Semarang.

Menurut Alexander Leighten dalam Moekijat (2000: 130) semangat kerja sebagai kemampuan sekelompok orang untuk bekerja sama dengan giat dan konsekuen dalam mengejar tujuan bersama. Menurut peneliti, semangat kerja adalah sikap individu atau kelompok untuk bekerja sama melakukan pekerjaan yang lebih giat dan sukarela sehingga pekerjaan dapat diselesaikan dengan lebih cepat dan lebih baik. Sedangkan semangat kerja dapat diukur melalui presensi pegawai ditempat kerja, tanggung jawabnya terhadap pekerjaan, disiplin kerja, kerja sama dengan pimpinan atau teman sejawat dalam organisasi serta tingkat produktivitas kerjanya (Hasley, 2003: 67). Untuk mengukur tinggi rendahnya semangat kerja pegawai dapat melalui unsur-unsur semangat kerja tersebut. Dalam penelitian ini indikator yang digunakan untuk mengukur semangat kerja adala sesuai dengan unsur-unsur semangat kerja.

Komunikasi menurut Carl I. Hovland (dalam Effendy, 2007: 10) adalah upaya yang sistematis untuk merumuskan secara tegar asas-asas penyampaian informasi serta pembentukan pendapat dan sikap. Sedangkan menurut Handoko (2001: 271) komunikasi adalah proses pemindahan pengertian dalam bentuk atau informasi dari seseorang ke orang lain.
Dari dua pengertian di atas peneliti simpulkan bahwa komunikasi adalah suatu hubungan dua orang atau lebih secara timbal balik dengan menggunakan lambanglambang yang bermakna berupa simbolsimbol atau kata-kata yang dapat digunakan untuk menyampaikan gagasan, pendapat atau informasi sehingga terjadi saling pengertian diantara keduanya.

Sedangkan organisasi menurut Gybson (dalam Muhyadi, 1991:5) yaitu kesatuan yang memungkinkan masyarakat mencapai berbagai tujuan yang tidak dapat dicapai hanya dengan kegiatan satu organisasi secara sendiri. Jadi komunikasi organisasi adalah sebagai komunikasi antar manusia (human communication) yang terjadi dalam konteks organisasi. Dari pengertian tersebut, maka kita dapat memahami bahwasannya komunikasi organisasi adalah proses komunikasi yang berlangsung secara formal maupun non formal dalam sebuah sistem yang disebut organisasi.

Komunikasi organisasi telah diidentifikasikan sebagai variabel yang paling banyak dipelajari dalam penelitianpenelitian tentang organisasi. Konsep tersebut telah menjadi sasaran sebagian besar pengamatan karena hipotesis hubungan antara komunikasi dan semangat kerja saling berkaitan. Penelitian Indriati (2005) tentang pelaksanaan komunikasi organisasi, lingkungan kerja dan pengembangan pegawai terhadap semangat kerja pegawai, dnegan sampel 114 orang pegawai Setda Kabupaten Grobogan, hasil penelitian membuktikan bahwa komunikasi organisasi berpengaruh terhadap semangat kerja. Selanjutnya penelitian Rochim (2012) yang meneliti pengaruh komunikasi, 
kepemimpinan dan lingkungan kerja terhadap semangat kerja guru dan karyawan dengan sampel 70 orang di SMK Pelita Nusantara 2 Semarang. Hasil penelitian menunjukkan bahwa komunikasi berpengaruh signifikan terhadap semangat kerja, artinya bahwa semakin inten komunikasi yang dilakukan maka akan semakin meningkatkan semangat kerja. Dari uraian di atas dapat diajukan suatu hipotesis sebagai berikut: komunikasi organisasi mempunyai pengaruh positif terhadap semangat kerja karyawan.

Menurut Handoko (2001: 155) kompensasi adalah segala sesuatu yang dapat diterima para karyawan sebagai balas jasa untuk kerja mereka. Sementara itu menurut Nawawi (2008: 315) kompensasi bagi perusahaan berarti penghargaan/ganjaran pada para pekerja yang telah memberikan kontribusi dalam mewujudkan tujuannya, melalui kegiatan yang disebut bekerja.

Kesimpulannya, kompensasi adalah segala sesuatu yang diberikan perusahaan kepada karyawan untuk memenuhi kebutuhan mereka baik dalam bentuk finansial maupun non finansial sebagai balas jasa perusahaan sehingga perusahaan dapat beroperasi dengan baik dan berusaha untuk mencapai tujuan perusahaan.

Menurut Simamora (2004: 442) bahwa indikator yang disajikan dalam menilai kompensasi adalah: (1) adil, (2) layak, (3) gaji dan upah, (4) insentif (tambahan kompensasi diluar gaji dan upah diberikan oleh perusahaan), (5) fasilitas (kompensasi yang diberikan oleh pihak perusahaan kepada karyawan sebagai penunjang kelancaran untuk bekerja dan memotivasi karyawan agar semangat kerja), (6) tunjangan (kompensasi tambahan yang diberikan berdasarkan kebijakan perusahaan terhadap semua karyawan dalam usaha untuk meningkatkan kesejahteraan karyawan). Sedangkan dalam penelitian ini indikator kompensasi yang digunakan adalah sesuai pendapat Simamora yaitu: adil, layak, gaji dan upah, insentif dan fasilitas.

Jika kompensasi yang diterima oleh karyawan layak dan adil, maka semangat kerja karyawan akan meningkat dengan baik. Hal ini diperkuat dengan hasil penelitian Danti (2014) menunjukkan bahwa kompensasi langsung dan tidak langsung berpengaruh terhadap semangat kerja karyawan. Dari kedua variabel tersebut, variabel kompensasi tidak langsung mempunyai pengaruh yang dominan terhadap semangat kerja karyawan. Dengan demikian penelitian ini juga mengajukan hipotesis kompensasi mempunyai pengaruh positif terhadap semangat kerja karyawan. Salah satu unsur untuk mengukur semangat kerja karyawan adalah salah satunya dengan komunikasi yang terjalin antara atasan dengan bawahan serta kompensasi yang diterima karyawan. Hal ini diperkuat dengan hasil penelitian Indriwati (2011) yang menunjukkan bahwa ada pengaruh positif dan signifikan komunikasi organisasi terhadap semangat kerja. Ada pengaruh positif dan signifikan kompensasi terhadap semangat kerja karyawan CV Indah Cemerlang Singosari Malang.

\section{METODE}

Semangat kerja merupakan perasaan yang memungkinkan seseorang bekerja untuk menghasilkan yang lebih banyak dan lebih 
baik (Hasley, 2003: 65). Semangat kerja dalam penelitian ini diukur dari presensi karyawan, tanggung jawabnya terhadap pekerjaan, disiplin kerja, kerja sama dengan pimpinan atau teman sejawat.

Variabel bebasnya adalah komunikasi organisasi $\left(X_{1}\right)$ dan kompensasi $\left(X_{2}\right)$. Komunikasi organisasi adalah sebagai komunikasi antar manusia (human communication) yang terjadi dalam konteks organisasi. Dalam penelitian ini komunikasi organisasi diukur dari: pertama, komunikasi vertical baik pihak pimpinan kepada bawahan (downward communication) maupun dari pihak bawahan kepada pimpinan (upward communication) (Gie, 2007: 66). Indikatornya yaitu pemberian perintah (instruksi), petunjuk-petunjuk, penjelasan-penjelasan, keteranganketerangan, larangan-larangan dan bahkan berupa pemberia hukuman atau sanksi. Sedangkan bawahan memberikan laporan, pendapat, saran, gagasann (ide), kreativitas, inisiatif kepada pimpinan (Nawawi, 2008: 124). Kedua, komunikasi horizontal yang berupa mengadakan pertemuan-pertemuan atau kegiatan musyawarah, rapat-rapat dan diskusi-diskusi (Gie, 2007: 67). Variabel kompensasi dalam penelitian ini indiaktornya sesuai pendapat Simamora (2004: 442) yaitu: adil, layak, gaji dan upah, insentif, fasilitas, dan tunjangan.

Penelitian ini menggunakan pendekatan kuantitatif (quantitative research) yaitu penelitian dengan menggunakan metode perhitungan statistik untuk memudahkan dalam menghitung data-data dari pengaruh komunikasi organisasi dan kompensasi terhadap semangat kerja karyawan PT. Vermindo Utama Semarang. Populasi dalam penelitian ini adalah seluruh karyawan PT. Vermindo Utama Semarang yang berjumlah 54 orang. Karena populasinya kurang dari 100 orang maka sampel dalam penelitian ini adalah semua karyawan PT. Vermindo Utama Semarang.

Data primer dalam penelitian ini diperoleh melalui kuesioner mengenai komunikasi organisasi, kompensasi dan semangat kerja karyawan PT. Vermindo Utama Semarang. Pengumpulan data menggunakan kuisioner (angket) dan wawancara. Analisis data menggunakan regresi linier berganda.

\section{HASIL DAN PEMBAHASAN}

PT. Vermindo Utama Semarang adalah perusahaan yang bergerak dibidang distributor obat-obat herbal salah satunya adalah obat Vermin yang terbuat dari cacing tanah dan obat tersebut digunakan untuk menurunkan penyakit demam dan tipus. PT. Vermindo Utama bertempat di Jl. Pawiyatan Luhur nomor 25 Semarang. Karyawannya berjumlah 54 orang.

Analisis statistik yang digunakan dalam penelitian ini yaitu regresi linier berganda. Analisis ini digunakan untuk mengetahui besarnya pengaruh variabel-variabel bebas (independent) yaitu komunikasi organisasi (X1), dan kompensasi (X2) terhadap variabel terikat (dependent) yaitu semangat kerja $(Y)$. Besarnya pengaruh variabel independent (komunikasi organisasi dan kompensasi) dengan variabel dependent (semangat kerja) secara bersama-sama dapat dihitung melalui persamaan regresi berganda.

Berdasarkan hasil perhitungan estimasi regresi pada Tabel 1 diperoleh nilai koefisien determinasi yang disesuaikan (adjusted $R^{2}$ ) 
adalah 0,692 artinya 69,2 \% variasi dari semua variabel bebas (komunikasi organisasi dan kompensasi) dapat menerangkan variabel terikat (semangat kerja), sedangkan sisanya sebesar 30,8 \% diterangkan oleh variabel lain yang tidak diajukan dalam penelitian ini.

Tabel 1. Hasil Analisis Regresi

\begin{tabular}{lcc}
\hline \multicolumn{1}{c}{ Variabel } & Koefisien & Signifikan \\
\hline Konstanta & 1,309 & 0,251 \\
Komunikasi Organisasi & 0,218 & 0,000 \\
Kompensasi & 0,415 & 0,000 \\
\hline $\mathrm{F}$ (p value) & 60,606 & $(0,000)$ \\
$\mathrm{R}$ & 0,694 & \\
Adjusted $\mathrm{R}^{2}$ & 0,692 & \\
$\mathrm{~N}$ & 54 & \\
\hline
\end{tabular}

Uji $t$ (t-test) ini dimaksudkan untuk mengetahui pengaruh secara parsial (individu) variabel-variabel independent (komunikasi organisasi dan kompensasi) terhadap variabel dependent (semangat kerja). Hasil uji t (t-test) dalam penelitian ini adalah: pertama, komunikasi organisasi nilai koefisien positif dan nilai signifikansi sebesar 0,000 lebih kecil dari 0,05 sehingga disimpulkan komunikasi organisasi berpengaruh terhadap semangat kerja. Kedua, variabel kompensasi mempunyai nilai koefisien positif dan nilai signifikansi 0,000 lebih kecil dari 0,05 sehingga disimpulkan kompensasi berpengaruh terhadap semangat kerja.

Berdasarkan pengujian hipotesis dapat dijelaskan bahwa variabel komunikasi organisasi dan kompensasi memiliki pengaruh kuat dalam menumbuhkan semangat kerja. Semakin baik komunikasi yang terjalin dalam organisasi dan besarnya kompensasi akan meningkatkan semangat kerja karyawan.

Setelah dilakukan uji $t$ (t-test), selanjutnya dilakukan uji $F$ (F-test). Hal ini dimaksudkan untuk mengetahui pengaruh variabel-variabel independent (komunikasi organisasi dan kompensasi) secara simultan (bersama-sama) terhadap variabel dependent (semangat kerja).

Dari hasil perhitungan output, nilai $F$ hitung sebesar 60,606 dengan nilai signifikan 0,000 lebih kecil dari 0,05 sehingga dapat disimpulkan komunikasi organisasi dan kompensasi secara bersama-sama berpengaruh positif terhadap semangat kerja karyawan.

Berdasarkan hasil penelitian secara statistik menunjukkan bahwa komunikasi organisasi dan kompensasi berpengaruh terhadap semangat kerja karyawan PT. Vermindo Utama Semarang. Komunikasi organisasi pada PT Vermindo Utama Semarang baik berupa komunikasi vertical yakni atasan dengan bawahan dan komunikasi horizontal yakni antara karyawan dengan karyawan di PT. Vermindo terjalin dengan baik. Informasi dari bawahan (karyawan) sampai kepada atasan (pimpinan) begitu sebaliknya pimpinan juga memberikan informasi dan perintah kepada karyawan sehingga dalam pekerjaan tidak terjadi miss communication.

Hasil penelitian yang dilakukan peneliti dengan hasil bahwa komunikasi organisasi berpengaruh positif terhadap semangat kerja, membuktikan dan memperkuat dari hasil penelitian terdahulu yakni dari Rochim (2012) yang menunjukkan bahwa komunikasi berpengaruh signifikan terhadap semangat kerja, artinya bahwa semakin inten 
komunikasi yang dilakukan maka akan semakin meningkatkan semangat kerja.

Selanjutnya hasil penelitian menunjukkan bahwa variabel kompensasi berpengaruh positif terhadap semangat kerja karyawan. Hal ini menunjukkan bahwa semakin besar kompensasi yang diterima oleh karyawan maka akan tinggi pula semangat kerja karyawan, karena tidak bisa dipungkiri bahwa kompensasi memang sangat dibutuhkan karyawan. Hasil penelitian ini membuktikan dan memperkuat hasil penelitian Danti (2014) yang menunjukkan bahwa kompensasi langsung dan tidak langsung berpengaruh terhadap semangat kerja karyawan.

\section{SIMPULAN}

Berdasarkan hasil penelitian dan pembahasan dapat disimpulkan sebagai berikut: pertama, komunikasi organisasi berpengaruh positif terhadap semangat kerja karyawan PT. Vermindo Utama Semarang. Hal ini berarti semakin baik komunikasi yang terjalin dalam perusahaan antara karyawan dengan atasan maupun karyawan dengan rekan sejawat akan meningkatkan semangat kerja, karena dengan komunikasi yang intens permasalahan dalam perusahaan akan mudah terselesaikan. Kedua, kompensasi berpengaruh positif terhadap semangat kerja karyawan PT. Vermindo Utama Semarang. Hal ini menunjukkan bahwa kompensasi baik berupa finansial maupun fasilitas akan meningkatkan semangat kerja karyawan, bagaimanapun juga kebutuhan karyawan adalah tanggungjawab perusahaan. Jika karyawan merasa nyaman, maka pekerjaan juga dapat mudah diselesaikan. Ketiga, komunikasi organisasi dan kompensasi secara bersama-sama berpengaruh positif terhadap semangat kerja karyawan PT. Vermindo Utama Semarang. Hal ini berarti komunikasi yang terjalin dengan baik dan kompensasi yang sesuai diberikan perusahaan kepada karyawan akan menjadikan semangat kerja karyawan meningkat.

\section{DAFTAR PUSTAKA}

Danti, Fajarrini P. (2014) Pengaruh Kompensasi terhadap Semangat Kerja. Jurnal Administrasi Bisnis, 9(2), 1-9.

Effendy, Onong Uchjana. (2007) IImu Komunikasi (teori dan Praktek) Bandung: PT. Remaja Rosdakarya.

Hasley, George D. (2003) Terjemahan oleh Anaf S. Bagindo. Bagaimana Memimpin dan Mengawasi Pegawai Anda. Jakarta: PT. Rineka Cipta.

Handoko, T. Hani. (2001) Manajemen Personalia dan Sumber Daya Manusia. Yogyakarta: BPFE.

Indriati, Tutik. (2005) Pengaruh Pelaksanaan Komunikasi Organisasi, Lingkungan Kerja dan Pengembangan Kerja terhadap Semangat Kerja Pegawai Kantor Sekretariat Daerah Kabupaten Grobogan. Laporan Penlitian. Semarang: Universitas Negeri Semarang.

Indriwati. (2011) Pengaruh Kompensasi dan Komunikasi Internal terhadap Semangat Kerja Karyawan CV. Indah Cemerlang Singosari Malang. Laporan Penelitian. Malang: Universitas Negeri Malang.

Gie, The Liang. (2007) Administrasi Perkantoran Modern. Edisi Keempat. Yogyakarta: Liberty.

Moekijat. (2000) Kamus Manajemen. Bandung: Penerbit CV. Mandar Maju. 
Muhyadi. (1991) Organisasi Teori Struktur dan Proses. Jakarta: Debdikbud.

Nawawi, Hadari. (2008) Manajemen Sumber Daya Manusia Untuk Bisnis Yang Kompetitif. Yogyakarta: Gadjah Mada Univesity Press.

Nitisemito, Alex. S. (2002) Manajemen Personalia. Edisi Revisi. Indonesia: Penerbit Ghalia.

Rochim, Nur. (2012) Analisis Pengaruh Komunikasi, Kepemimpinan dan
Lingkungan Kerja terhadap Semangat Kerja Guru dan Karyawan. Jurnal Dinamika Manajemen, 1(2), 103-113.

Simamora, Henry. (2004) Manajemen Sumber Daya Manusia. Edisi Ke-3. Yogyakarta: STIE YKPN.

Terry, George R. (2006) Principles of Management (Alih bahasa Winardi) Bandung: Penerbit Alumni.

Zainun, Buchari. (2000) Manajemen dan Motivasi. Jakarta: Balai Aksara. 